\title{
THE PARTHENON MARBLES REVISITED: A NEW STRATEGY FOR GREECE
}

\author{
NADIA BANTEKA*
}

\begin{abstract}
Cultural property disputes raise questions of ownership, possession, alleged destruction, and looting. They are also affected by legal vacuums, and idiosyncratic statutes of limitations. Should objects of cultural heritage that have been removed in the past be returned to their source nation? This article discusses the perennial claim Greece made to the British Museum for the return of a collection of sculptures from the Parthenon and the Acropolis of Athens. This article identifies a trajectory towards a more effective approach on cultural property disputes transcending the traditional ownership versus value debate. It advocates a shift of the discussion from one of legal title and ownership to one of negotiation, cooperation, and advancement of both nationalist and internationalist ideals. This article adds a new spin to an old unresolved debate by advancing two primary arguments: (1) an inalienability argument based on Margaret Radin's theory of personhood; and, in the alternative, (2) a reassessment of the cultural nationalism/internationalism debate, and a negotiation strategy based on prior successful returns of cultural property objects. First, Margaret Radin's theory of personhood gives the country of origin a normative argument against typical commensurate perceptions of

\footnotetext{
* Lecturer in International Law, The Hague University of Applied Sciences;
} S.J.D. (Cand.) University of Pennsylvania Law School; Visiting Scholar, Columbia Law School. I would like to thank Sharon Neill Lorenzo; the participants of 10th Annual International Conference in Law of the Athens Institute for Education and Research; and the participants of the Second International Colloquy: "Parthenon. An Icon of Global Citizenship," for their valuable feedback on earlier drafts. Thank you also to Svetlana Atanasova and Martin Tasev for their excellent research assistance. Finally, thank you to the editors of the University of Pennsylvania Journal of International Law for their constructive edits. All remaining errors are my own.
\end{abstract}


property. Second, and in the alternative, instead of approaching cultural nationalism and internationalism as mutually exclusive, the two can flourish together under clarified objectives that do not mesh with each other's agendas but rather bolster one another. Finally, this article examines successful return strategies under this new integrated cultural nationalism/internationalism approach using the Four Quadrant Negotiation Model. Ideas such as loan agreements, trading and exchange of cultural artifacts, touring collections, exclusive excavation agreements, joint trusteeship, fractional ownership, personnel education, and liability waivers provide starting points in a negotiation on how to form a partnership between Greece and the British Museum that will promote collaboration, international exchange of cultural heritage, public access, and education. 


\section{TABLE OF CONTENTS}

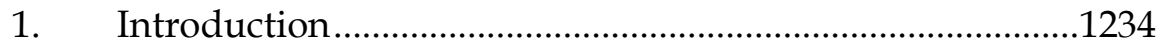

2. History of the Parthenon Marbles Acquisition.....................1237

3. The Inalienability of the Parthenon Marbles ........................1241

3.1. A Theory of Cultural Property Inalienability.......................1241

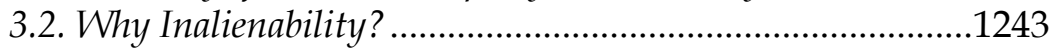

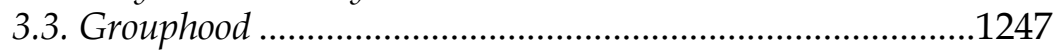

3.4. A Non-Fetishistic Claim .....................................................1251

4. Cultural Nationalism \& Cultural Internationalism .............1252

4.1. Cultural Nationalism ......................................................1253

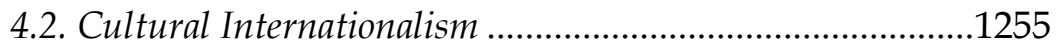

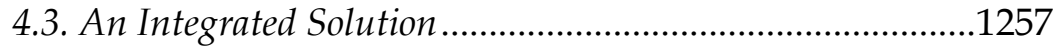

5. A New Return Strategy for Greece...................................1259

5.1. Successful Returns ............................................................1259

5.2. Loan Strategy - The Euphronios Krater..............................1261

5.3. A New Negotiation Strategy for Greece .............................1263

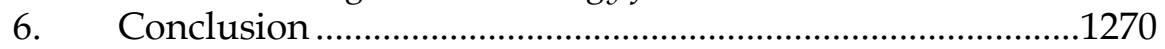




\section{INTRODUCTION}

The history of a nation is intrinsically connected to the legacy of its ancestors. This legacy attaches to pieces of cultural heritage that survive at any given point in time, which constitutes the present. In today's globalized world, cosmopolitan ideals suggest that these pieces of national heritage also constitute parts of the heritage of all mankind individually and in the aggregate. Not only do they facilitate an individual nation's linkages with its past to better understand its present and identity, but also elucidate the historical context of all mankind by providing reference and educating the world on its progression. Though both sides of the cultural heritage coin are invaluable, they also come to be in conflict, especially when a piece of cultural heritage originating from one nation finds itself in the possession of another without the former's clear consent. Questions of ownership, possession, and distribution of cultural property have their roots on this precise duality of belonging that is intrinsic to the idea of cultural heritage the way our civilization understands it.

But it is not possible to have a discussion on ownership of cultural property without having at least a working definition of the term. Cultural property was for a long time an undefined concept that was used as a term of convenience for lack of a better alternative. The development of International Law created the need for legal definitions of such terms that had been customarily in use as part of our collective vocabulary. The term "cultural property" was first officially used within International Law in the Hague Convention for the Protection of Cultural Property in the Event of Armed Conflict of $1954 .^{1}$ Under this convention, cultural property involves "movable and immovable property of great importance to the cultural heritage of every people," 2 buildings, monuments, and museums of cultural importance, ${ }^{3}$ as well as "centers containing large amounts of cultural property" such as cities. ${ }^{4}$ A more recent definition of cultural property was provided in the UNESCO Convention on the Means of Prohibiting and Preventing the Illicit Im-

1 Convention for the Protection of Cultural Property in the Event of Armed Conflict, May 14, 1954, 249 U.N.T.S. 240 [https://perma.cc/QP85-U2RD] [hereinafter 1954 Hague Convention].

2 Id. at art.1.

3 Id.

$4 \quad$ Id. at $\S(\mathrm{c})$. 
port, Export, and Transfer of Ownership of Cultural Property of 1970.5 While the UNESCO Convention provides a fairly detailed definition of cultural property, it more generally conceives it as "property, which, on religious or secular grounds, is specifically designated by each State as being of importance for archaeology, prehistory, history, literature, art or science." 6

Cultural property has acquired a unique status as a form of property-one that is real property enough in order to constitute tangible objects, and personal property enough to receive special protection status. ${ }^{7}$ Cultural property transcends the usual commodifiable and fungible conceptions of property and becomes an extension of nationhood in the same way as property for Hegel is an extension of personhood. ${ }^{8}$ However, this ideal of cultural prop-

5 Convention on the Means of Prohibiting and Preventing the Illicit Import, Export and Transfer of Ownership of Cultural Property, Nov. 14, 1970, 823 U.N.T.S. 232, 234, art. 1 [https://perma.cc/8DZT-M23C] [hereinafter UNESCO Convention 1970] (enumerating items that constitute cultural property as follows: "(a) rare collections and specimens of fauna, flora, minerals and anatomy, and objects of paleontological interest; (b) property relating to history, ranging from the history of science, technology, military, social history, to the life of national leaders, thinkers, scientists and artists and to events of national importance; (c) products of archaeological excavations (including regular and clandestine) or discoveries; (d) elements of artistic or historical monuments, or dismembered archaeological sites; (e) antiquities more than one hundred years old, such as inscriptions, coins, and engraved seals; (f) objects of ethnological interest; (g) property of artistic interest, such as (i) pictures, paintings and drawings produced entirely by hand on any support and on any material (excluding industrial designs and manufactured articles decorated by hand); (ii) original works of statuary art and sculpture in any material; (iii) original engravings, prints and lithographs; and (iv) original artistic assemblages and montages in any material; (h) rare manuscripts and incunabula, old books, documents and publications of special interest (historical, artistic, scientific, literary, etc.), singly or in collections; (i) postage, revenue or similar stamps, singly or in collections; (j) archives, including sound, photographic, and cinematographic archives; $(\mathrm{k})$ articles of furniture more than one hundred years old, and old musical instruments.").

6 Id.

7 Laura S. UnderkUfFler, the Idea OF Property: Its MEANING AND POWER 110 (2003). See also UNESCO Convention 1970 supra note 6, at 234 and 236, 96 Star at 2351 (defining cultural property as "specifically designated by each State as being of importance for archeology, prehistory, history, literature, art or science and which belongs to" one of a list of eleven categories). See also the implementing legislation enacted in 1983, Convention on Cultural Property Implementation Act, Pub. L. No. 97-446, 96 Stat. 2350 (codified at 19 U.S.C. §§ 2601 - 2613 (2000)) (relying on a similar definition).

8 Civil society can be understood as a community of possession, with each individual owning property as the embodiment of spirit. G.W.F. HEGEL, ELEMENTS OF THE PHILOSOPHY OF RIGHT 77 - 81 (Allen W. Wood ed., H.B. Nisbet trans., 1991) [https://perma.cc/E7MX-M8WR]. See also Margaret Jane Radin, Property and Personhood, 34 STAN. L. REV. 957, 959 (1982) [https://perma.cc/8YUJ-WKHG] (arguing that 
erty protection and conservation does not go far back in time as a definitive legal obligation. The legal framework in place is of restrictive application due to temporal constraints. The first ideas on cultural property protection vaguely came into being after the 1899 and 1907 Hague Conventions, ${ }^{9}$ with their express realization only in 1954. Issues of controversy, including alleged cultural property destruction, looting, and contended ownership claims are locked into an idiosyncratic statute of limitations.

This temporal legal lacuna has, of course, been the cause of a tremendously rich legal scholarship trying to settle claims not covered by the current legal regime. These claims maintain their relevance due to their consistent elevation in academic, political, and civic interest. This article is concerned with what arguably constitutes the perennial claim; the claim Greece made to the British $\mathrm{Mu}$ seum for the return of a collection of sculptures from the Parthenon and the Acropolis of Athens that is in its possession. ${ }^{10}$ Part I of this article briefly discusses the history of the issue and the arguments raised by both the Greek and British sides. Part II brings forward an inalienability argument based on Margaret Radin's theory of personhood. This gives the country of origin a normative argument proposing a link between property and personhood against typical commensurate perceptions of property. Part III critically examines the debate between cultural nationalism and cultural internationalism in an attempt to establish a modest standard in cultural property exchange. Finally, Part IV aligns with this more modest position between cultural nationalism and international-

certain property is "part of the way we constitute ourselves as continuing personal entities in the world").

9 Convention with Respect to the Laws and Customs of War on Land, July 29, 1899, 32 Stat. 1803, T.S. No. 403, 26 Martens Nouveau Recueil (ser. 2) 949, reprinted in 1 AM. J. INT'L L. 129 (1907) [https://perma.cc/N2TJ-8BDV] [hereinafter 1899 Hague Convention II]. Convention Respecting the Laws and Customs of War on Land, Oct 18, 1907, 36 Stat. 2277 (1907), T.S. No. 539, 3 Martens Nouveau Recueil (ser. 3) 461, reprinted in 2 AM. J. INT'L L. 90 (1908) [https://perma.cc/59SZ-6A7R] [hereinafter 1907 Hague Convention IV].

10 Hereinafter referred to as "The Parthenon Marbles"; The Pantheon Marbles in question include: 15 metopes from the south side of the ancient temple, 56 reliefs from the frieze, 19 sculptures from the two pediments, other fragments belonging to the aforesaid units, one column capital, one column drum and one thronos. See Hellenic Ministry of Culture, Memorandum on the Parthenon Marbles submitted by the Government of the Hellenic Republic to the House of Commons Select Committee on Culture, Media and Sport (Mar. 9, 2000) available at http://odysseus.culture.gr/a/1/12/files/memorandum.pdf [https://perma.cc/4SNM$3 \mathrm{SNW}$ (providing an overview of the controversy). 
ism, examines past successful return strategies, and proposes an integrated approach under a new negotiation process.

\section{HISTORY OF THE PARTHENON MARBLES ACQUISITION}

The Ottoman Turks conquered Greece in 1453 and ruled in that space until the Greek War of Independence and subsequent emancipation in 1828.11 Between 1801 and 1812 Thomas Bruce, 7th Earl of Elgin, who served as British Ambassador to the Sublime Porte ${ }^{12}$ of the Ottoman Empire, ${ }^{13}$ removed parts of the Parthenon marble sculptures and shipped them to England. ${ }^{14}$ Consistent with the era's trend of acquiring antiquities in order to decorate estates in the British countryside, Elgin ordered several of his architects and craftsmen to Athens to measure and make casts for his new country home in Scotland. ${ }^{15}$ Elgin sought permission by the Ottoman authorities at a time when the Ottomans were on good terms with the British, which he allegedly received in the form of a firman, a royal decree designed to grant permission to perform the acts prescribed to the beneficiary. ${ }^{16}$ Elgin proceeded as planned with his architects and drafters who, as vividly described by Greek official sources,

11 JEANETTE GREENFIELD, THE RETURN OF CULTURAL TREASURES 55 (2d ed. 1996).

12 The Western powers used the term "Sublime Porte" to refer to the Government of the Ottoman Empire in Constantinople. STANFORD J. SHAW, HISTORY OF THE OtTOMAN EMPIRE AND TURKEY 119 (1976). See H. INALCIK, THE OTTOMAN EMPIRE: CONQUEST, ORGANIZATION AND ECONOMY 112, 129 (1978) (describing how the Sultan was the supreme Ottoman authority, with absolute authority over subjects and property in the empire, subject only to the restraints of Islamic law). See ibid at 58. See also J. UBICINI, LETTERS ON TURKEY 33 - 34 (1856 \& photo. reprint 1973) [https://perma.cc/87LQ-83VH] (explaining that the Grand Vizier, "the Bearer of Burdens," was second in command only to the Sultan and was the head of the executive power of the Government). See W. Vucinich, THE OTTOMAN EMPIRE 26 (1965).

13 John H. Merryman, Thinking About the Elgin Marbles 1882 (2d ed. 2009).

14 See M. Ounanian, Of All The Things I've Lost, I Miss My Marbles The Most! An Alternative Approach to the Epic Problem of the Elgin Marbles, 9 CARDOZO J. CONFLICT RESOL. 109, 112 (2007-08) [https://perma.cc/52PS-LFQU] (describing the chain of events that led to Elgin removing the Marbles).

15 See GREENFIELD, supra note 12, at 55 (describing the process and motivations behind Elgin's removal of the artifacts from Greece).

16 Id. 
took down the sculptures from the temple where they had been standing for some 2,250 years, destroying in the process the surrounding parts of the structure, sawing off the backs of the frieze blocks in order to break them off, cutting in two one of the Parthenon capitals and an Erechtheion cornice, carelessly smashing one of the metopes . . . ${ }^{17}$

Upon arrival in England, Elgin stored the Parthenon Marbles until he was successful in persuading the British government in 1816 to purchase them on behalf the British Museum for the price of $£ 35,000.18$ Ever since, the British Museum has displayed the Parthenon Marbles in a special room created to host them, and has referred to them as "The Elgin or Parthenon Marbles." 19

After Greece gained its independence, Greek authorities filed multiple requests for the return of the Parthenon Marbles. ${ }^{20}$ The most emblematic campaign took place in 1983 and was represented by Melina Mercouri, a famous actress serving as the Greek Minister of Culture at the time. ${ }^{21}$ The British Government officially declined this request in 1984. ${ }^{22}$ The British Government has since retained a consistent position on the debate having declined all subsequent requests for full return of the Parthenon Marbles. The core of the issues on the legal debate over the Parthenon Marbles is the authority of those who gave Elgin permission, and the scope of

\footnotetext{
17 Russell Working, The Parthenon Marbles: Tussling Over a Stolen Treasure, JAPAN TIMES, Aug. 6, 2002, available at http://www.japantimes.co.jp/life/2002/08/06/travel/tussling-over-a-stolentreasure/\#.VvZLL5MrLBJ.

18 See GREENFIELD, supra note 12, at 59 (describing the negotiation between Elgin and the British government in the nineteenth century).

19 J.H. Merryman, Thinking about the Elgin Marbles, 83(8) MichigAN LAW REVIEW 1880, 1882 (1985). For recent historical discussions see J. ROTHENBERG,

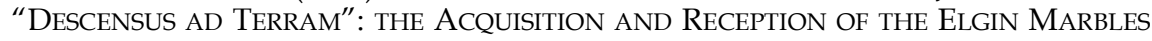
(Garland Pub. 1977); W. ST. Clair, LORD Elgin AND the MArbles (2d ed. 1983). There is a collection of materials about the Marbles in J. MERrYMAN \& A. ELSEN, LAW, ETHICS AND THE VISUAL ARTS 1 - 4 to 1 - 26 (5th ed., 1979).

20 Greece began petitioning for the Parthenon Marbles' return soon after they achieved independence from the Turks in 1832 and made a formal request through the United Nations. GREENFIELD, supra note 12, at 72. See also W. ST. CLAIR, supra note 20, at $272-73$ (discussing the earlier appeals for the return of the Parthenon Marbles).

21 John Henry Merryman, Thinking about the Elgin Marbles: Critical EsSAYs On CUltural Property, ART AND LAW 24 (2nd ed. 2011).

22 Id.
} 
that authority. ${ }^{23}$ Under the common law principle of nemo dat quod non habet, ${ }^{24}$ the Crown can acquire no better title to the objects than what was acquired by Elgin, ${ }^{25}$ granting protection to the original owner through the form of an estoppel. ${ }^{26}$ If Lord Elgin owned the Parthenon Marbles under good title, he could consequently transfer ownership to the Crown. If his title was defective, then so was the Crown's title.

The British side has consistently provided four main arguments in favor of the retention of the Parthenon Marbles by the British Museum. First, they sustain that Elgin's title to the Parthenon Marbles was good under the International Law applicable at the time of Lord Elgin's actions, ${ }^{27}$ and in accordance with the doctrine of intertemporal law. ${ }^{28}$ Second, the presence of the Parthenon

23 See GREENFIELD, supra note 12, at 59 (covering the legal arguments made by the British government in this dispute over Greek artifacts taken by Elgin).

24 Mitchell v. Hawley, 83 U.S. 544 (1872) (stating the general principle: No one in general can sell personal property and convey a valid title to it unless he is the owner or lawfully represents the owner. Nemodat quod non habet. Persons, therefore, who buy goods from one not the owner, and who does not lawfully represent the owner, however innocent they may be, obtain no property whatever in the goods, as no one can convey in such a case any better title than he owns, unless the sale is made in market overt, or under circumstances which show that the seller lawfully represented the owner).

25 The Sale of Goods Act 1979 establishes: Subject to this Act, where goods are sold by a person who is not their owner, and who does not sell them under the authority or with the consent of the owner, the buyer acquires no better title to the goods than the seller had, unless the owner of the goods is by his conduct precluded from denying the seller's authority to sell. Section 21(1) Sale of Goods Act 1979 [https://perma.cc/73MW-2Z8G].

26 John Cartwright, Protecting Legitimate Expectations and Estoppel in English Law, 10 (3) EleCtRONIC J. OF COMP. L. 1, 2 - 5 (Dec. 2006), available at http://www.ejcl.org/103/art103-6.pdf [https://perma.cc/P99B-5LBB].

27 The Parthenon Sculptures, THE BRITISH MUSEUM, http://www.britishmuseum.org/about_us/news and press/statements/parthenon_s culptures.aspx [https://perma.cc/C̄P63-6JYL].

28 See Daniel-Erasmus Khan, Max Huber as Arbitrator: The Palmas (Miangas) Case and Other Arbitrations, 18 EJIL 145, 167 (2007) [https://perma.cc/B64X-3SAX] (discussing the changing conditions as regards to certain specific international law principles throughout a lapse of time, more specifically that a law has to be interpreted according to the law contemporary to it). See also T. O. Elias, The Doctrine of Intertemporal Law, 74 AM. J. INT'L L., 287 (1980) [https://perma.cc/2GMA-8QMZ] ("a juridical fact must be appreciated in the light of the law contemporary with it, and not of the law in force at the time when a dispute in regard to it arises or falls to be settled"). For relevant jurisprudence on the matter see generally M. SHAW, INTERNATIONAL LAW 429 (5 $5^{\text {th }}$ ed., 2003) [https://perma.cc/TN4L-AY7F]; Island of Palmas Case (Netherlands, U.S.A.), United Nations, 2 Reports of International Arbitral Awards 845 [https://perma.cc/484X-7D8U]; Land and Maritime Boundary between Cameroon and Nigeria (Cameroon v. Nig.), 2002 I.C.J. 105 (June 16) 
Marbles in the British Museum over the course of time has protected them from potential damage due to exposure to the open-air conditions of the Acropolis rock. ${ }^{29}$ Third, the British sustain that the Parthenon Marbles have become an integral part of British cultural heritage not only due to their presence there for more than a century, but also due to the effect they have had on British art through the neoclassical movement. ${ }^{30}$ Finally, they assert that a potential return of the Parthenon Marbles to Greece could set a precedent that may turn into a ripple effect towards a likely universal removal of world museums' acquisitions ${ }^{31}$ from the socalled "source countries." 32

On the other hand, Greece has advocated for the return of the Parthenon Marbles to Athens on four principal counter-arguments. First, the Greeks maintain that the monument the Parthenon Marbles belong to is situated in Athens, ${ }^{33}$ and by extension, the Parthenon Marbles ought to be in proximity to the monument they were built to embellish. Second, they make an emotional plea for the Parthenon Marbles forming part of an inseparable monument epitomizing the apogee of the Greek Classical Civilization, which to this day stands as the cradle of Greek past and present. ${ }^{34}$ Third, the British are under an obligation not only to Greece but to mankind to unify and restore the Parthenon, a monument that not only is one of the "world miracles" but is also the emblem of UNESCO. ${ }^{35}$ Finally, and perhaps most practically, a potential restitution of the Parthenon Marbles in Athens will allow for their ex-

[https://perma.cc/3TZX-3QV7] (separate opinion of Judge Al-Khasawneh) [hereinafter Land and Maritime Boundary Case].

29 See supra note 28. (showing and describing the open-air acropolis and its exposure damage).

$30 \quad I d$.

31 See id. (outlining the policy arguments of the British government in the dispute over Greek artifacts).

32 See Roger W. Mastalir, A Proposal for Protecting the 'Cultural' and 'Property' Aspects of Cultural Property Under International Law, 16 FORDHAM INT'L L. J. 1033, 1056 (1993) [https://perma.cc/L3GG-P5EH] (explaining the notion that cultural property is intertwined and linked to the source country under the UNESCO Convention 1970).

33 See Demands of the Greek Government: Why Athens and Not London, HeLLENIC ELECTRONIC CENTER, http://www.greece.org/parthenon/marbles/greece.htm (explaining the Greek argument for the location of the Marbles to be in Greece, reunifying the Parthenon).

34 Id.

35 See id. (describing how the Marbles may be under ownership of UNESCO, but the ownership is not the key issue). 
hibit in close proximity to the sight of the Parthenon, in a state-ofthe-art museum, the Acropolis Museum, built especially for the purpose of housing them. ${ }^{36}$ World visitors will have the unique opportunity of enjoying the monument to its fullest ${ }^{37}$ at the space where the artists intended for it to be enjoyed.

\section{THE INALIENABILITY OF THE PARTHENON MARBLES}

\subsection{A Theory of Cultural Property Inalienability}

Arguments have been offered advocating the inalienability of certain types of cultural property due to their constitutive nature over the identity of the group that created them. Such property may not be alienated because any transaction leading to alienation could threaten the continuing existence of the group. Objects falling under this classification ought to be treated not as commodifiable and fungible, but rather as singular constitutive elements of grouphood. Margaret Radin's theory of personhood ${ }^{38}$ applied to the case of the Parthenon Marbles produces a set of compelling arguments in favor of inalienability. In opposition to the de jure inalienability of British Museum collection objects, Radin's theory provides Greece with a normative yet efficacious argument against the original alienation of the Parthenon Marbles detached from the individual acts pertaining to it.

Margaret Radin's atypical property theory proposed a link between property and personhood that fundamentally altered com-

36 The Acropolis Museum Officially Inaugurated, HeLLENIC REPUBLIC EMBASSY OF GReEce IN POlAnd PRESS AND COMMUnicAtion OfFICE, Jun. 23, 2009, https://greeceinfo.wordpress.com/2009/06/23/the-acropolis-museum-officiallyinaugurated/ [https://perma.cc/G5VX-66W6]. See also New Acropolis Museum Wins Prestigious Award, ATHENS NeWS, Nov. 8, 2012, http://archive.is/SWKR [https://perma.cc/YX5M-Z458] (announcing the inauguration event for the new museum); Spyros Kouvoussis, Acropolis Museum's Laser Technique Wins Keck Award, Sep. 18, 2012, http://greece.greekreporter.com/2012/09/18/acropolismuseums-laser-technique-wins-keck-award/ [https://perma.cc/P8AH-R968] (describing a conservation technique exemplifying the state of the art nature of the Parthenon museum).

37 See supra note 34 (holding the return of the sculptures would unify a unique monument).

38 John Moustakas, Group Rights in Cultural Property: Justifying Strict Inalienability, 74 CORNELL L. REV. 1179, 1184 (1989) [https://perma.cc/37JE-F8RK]. 
mensurate perceptions towards property. ${ }^{39}$ At the core of Radin's theory is the idea that some property is entitled to a higher level of legal protection due to its expression of individual personhood; 40 such property, Radin argues, should be non-fungible. ${ }^{41}$ Radin rejected the prevailing notion that all property is universally commodifiable and alienable ${ }^{42}$ by expounding that property constitutive to personhood should be legally protected against market incursions and government interference. ${ }^{43}$ Radin predicated this individualized regulation on the personal nature of certain types of property. ${ }^{4}$ To understand the significance of a person's relationship with an object is to examine "the kind of pain that would be occasioned by its loss." 45 The type of pain envisioned here is one that "cannot be relieved by the object's replacement ${ }^{46}$ with other goods of equal market value." 47 Radin carves out one exception to

39 Three decades after Radin's publication of Property and Personhood, her widely applied theory hardly appears radical. See, e.g., Kristen A. Carpenter, Real Property and Peoplehood, 27 STAN. ENVT'L. L. J. 313, 345 (2008) [https://perma.cc/3Z48K2LC] (identifying scholarship that applies Radin's theory to the cultural property context); Stephen J. Schnably, Property and Pragmatism: A Critique of Radin's Theory of Property and Personhood, 45 STAN. L. REV. 347, 349 (1993) [https://perma.cc/H9Y5ZZFG] (surveying the influence of Radin's theory of property and personhood).

40 See Radin, supra note 9, at 959 (arguing, on an "intuitive" level, that most individuals possess certain objects that are "almost part of themselves," including wedding rings and family heirlooms).

41 Id. at $959-61,986-88$.

42 Margaret Jane Radin, CONTESTed Commodities 8 - 15 (1996) [https://perma.cc/TP7W-ACZP].

43 See Radin, supra note 9, at 1014 - 15 (arguing that personal property rights "should be protected to some extent against invasion by government and against cancellation by conflicting fungible property claims of other people," and fungible property rights "should yield to some extent in the face of conflicting recognized personhood interests").

44 Radin has authored dozens of articles and several books exploring specific personal themes of property. See generally MARGARET JANE RADIN, REINTERPRETING PROPERTY (1993) [https://perma.cc/B6GC-SYRY]; Margaret Jane Radin, Contested Commodities, in RETHINKING COMMODIFICATION: CASES AND READINGS IN LA AND Culture 81 (Martha M. Ertman \& Joan C. Williams eds., 2005); Margaret Jane Radin, The Liberal Conception of Property: Cross Currents in the Jurisprudence of Takings, 88 CoL. L. REV. 1667 (1988) [https://perma.cc/YC4K-TYLL]; Margaret Jane Radin, Market-Inalienability, 100 HARV. L. REV. 1849 (1986) [https://perma.cc/YS7X-4NRY] [hereinafter Radin, Market-Inalienability]; Margaret Jane Radin, Property Evolving in Cyberspace, 15 J.L. \& COM. 509 (1996) [https://perma.cc/H8PL-HPCJ].

45 See Radin, supra note 9, at 959 (arguing that a relationship exists between the pain an individual feels and how important the art is to that individual).

$46 \quad I d$.

47 See id. at 959 - 960 (recognizing that sentimental value cannot always be monetized). 
the idea of inalienable personal property in what she calls "bad object relations" or "fetishism." A person's relationship with an object becomes fetishistic when the attachment with the object is inhibiting one's ability to develop a healthy identity. ${ }^{48}$

In a similar vein and making an even broader point, Patty Gerstenblith stresses that once items are designated as cultural property they assume a special role that links identity with ownership. That is because the identity of a people is inextricably linked to the object, rendering a group unable to consent to transactions that would alienate it. If such were permitted, future generations would, by default, be unable to consent to transactions that could affect their own identity and culture. ${ }^{49}$ Gerstenblith's argument echoes an application of Radin's theory on groups instead of individuals under the premise that cultural property is "that specific form of property that enhances identity, understanding, and appreciation for the culture that produced [it]."50 Cultural property epitomizes the kind of personal property Radin had in mind, simply applied to a group rather than an individual. ${ }^{51}$ The constitutive nature of certain cultural property objects to a group's collective and individualized identities calls for treatment transcending that of an ordinary market transaction, and against their commodification. ${ }^{52}$ This is in line with Radin's contention that "[a] person cannot be fully a person without a sense of continuity of self over time." 53 Ongoing relationships between individuals or groups and personal property maintain that sense of continuity. ${ }^{54}$

\subsection{Why Inalienability?}

Traditional scholarship discusses the problem of involuntary dispossession of cultural property through the emergence of national and international rules prohibiting it, without considering

\footnotetext{
48 Id. at 970.
}

49 See Patty Gerstenblith, Art, Cultural Heritage, AND the LaW 570 (2004) [https://perma.cc/4PZ4-KXQ8] (stating that a final reason stems from the Lockean possessive individualism premise that the property may be the product of group effort and labor).

$50 \quad$ Id. at 569.

51 See id. at 570 (arguing that the relationship an individual possesses with a work of art is also applicable to a society).

52 Kristen Carpenter, In Defense of Property, 118 YALE L.J. 1022, 1048 (2009) [https://perma.cc/3RLG-YQG8].

53 Radin, supra note 9, at 1004.

$54 \quad$ Id. 
the possibility of inherent inalienability. ${ }^{55}$ Inalienability arguments usually spark controversy considering property is by default presumed to be alienable. ${ }^{56}$ Inalienability, as a "stepchild of law and economics" 57 is perceived as a set of unnecessary and inefficient constraints on market trades and economic liberty through paternalistic and moralist claims. ${ }^{58}$ But, upon further inspection, inal-

55 Moustakas, supra note 39, at 1203. See id. (citing Lawrence J. Persick, The Continuing Development of United States Policy Concerning the International Movement of Cultural Property, 4 PENN ST. INT'L L. REV. 89, 97 (1985) [https://perma.cc/29PX-T7MW]) (describing how, based on a system of import and export restrictions, UNESCO Convention 1970 protects cultural property only to the extent that an individual nation creates such restrictions); id. (citing Persick) ("But even those countries that have nationalized their cultural property and claim any export violates their national law have met with uncertain results. 'International legal authorities consider these laws complicated and ambiguous, causing problems not only for the governments that enacted them but also for those nations in which the importation of art is "big business." '); id. (quoting Rogers, The Legal Response to the Illicit Movement of Cultural Property, 5 LAW \& POL'Y INT'L BUS. 932, 934 - 35 (1973)) (“'The developed nations have been reluctant to assist in enforcing such bans because of what they perceive as clearly legitimate interests in the free international flow of art.' "); id. (citing Rogers) ("Moreover, critics argue that such bars create and perpetuate the black market, ultimately undermining protection."); id. (citing Merryman \& Elsen, supra note 11, at 6) ("delineating, among other things, "the elements of an interest sensitive and enforceable international policy toward art smuggling and theft ....'").

56 See Radin, Market-Inalienability, supra note 45 at 1851 (questioning the inalienable right of property possession). See also LAWRENCE BECKER, PROPERTY Rights: PHILOSOPHIC Foundations 20 (1977) (“'The right to capital] is the most fundamental ... . of the elements, if only because it includes the right to destroy, consume, and alienate."). But according to Grey, "discourse about property has fragmented into a set of discontinuous usages." THOMAS GREY, THE Disintegration of PROPERTY, IN NOMOS XXII: PROPERTY 72 (Penncock and Chapman ed., 1980) [https://perma.cc/U96F-XS3W]. The notion of a bundle of rights in property explains the modern view of property in which both the traditional notion of ownership has dissolved, and the necessary connection between property rights and things has been eliminated. Id. at 69. Andrus v. Allard, 444 U.S. 51 (1978) [https://perma.cc/2RBK-9XZR], is consistent with this approach. Andrus upheld a prohibition against the sale of bird parts lawfully taken before the effective date of federal protection pursuant to the Eagle Protection Act. The prohibition did not affect a taking because the regulations challenged [...] do not compel surrender of the artifacts, and there is no physical invasion or restraint upon them. Rather, a significant restriction has been imposed on one means of disposing of the artifacts. But the denial of one traditional right does not always amount to a taking. At least where an owner possesses a full "bundle" of property rights, the destruction of one "strand" of the bundle is not a taking, because the aggregate must be viewed in its entirety. Id., at $65-66$.

57 S. Rose-Ackerman, Inalienability and the Theory of Property Rights, 85 ColuM. L. REV. 931, 931 (1985) [https://perma.cc/9PS9-YX4U].

58 See generally Calabresi \& Melamed, Property Rules, Liability Rules, and Inalienability: One View of the Cathedral, 85 HARV. L. REV. 1089 (1972) [https://perma.cc/E2UP-Y99Q]. 
ienability represents a highly interesting concept that combines market standards with non-economic rights and ideals such as those of citizenship and distributive justice. ${ }^{59}$

Radin prescribes that an inalienability regime is necessary for the promotion of property for personhood. Through setting restrictions on transferability of cultural property, Radin's theory avoids a potential commodification of cultural property, shifting the discussion to notions of communal flourishing, ${ }^{60}$ and intergenerational justice, ${ }^{61}$ without lapsing into paternalism. Cultural property is the optimal scenario for the application of inalienability restrictions out of most types of property. There are three grounds on which the alienability of property for personhood would warrant its prohibition: (1) Radin argues that due to its intrinsic nature, a potential alienation of such property would most likely be the effect of coercion. ${ }^{62}$ By establishing an inalienability regime, the market protects free choice and liberty. (2) The concept of human flourishing that derives from inalienability is substantively superior to that fostered by the commodifiable market conception of human flourishing.63 And (3) in the context of property for grouphood, distributive intergenerational justice mandates that certain objects be inherently inalienable in order to safeguard the flourishing of future generations belonging to the group. ${ }^{64}$

59 See Rose-Ackerman, supra note 58 at 173.

60 Communal flourishing is merely an analogue to the concept of human flourishing developed by Radin. If individuals can experience flourishing as a result of their relationships with objects, presumably a group can similarly flourish given the proper object-relation. See Radin, Market-Inalienability, supra note 45, at 1903 - 1909.

61 The concept of intergenerational justice envisions certain obligations running through time to past or succeeding future generations, or both. A commitment to intergenerational concerns is usually expressed by sensitivity to distributive fairness between generations. See Sterk, Freedom from Freedom of Contract: The Enduring Value of Servitude Restrictions, 70 IOWA L. REV. 615, 634 n.86 (1985) [https://perma.cc/SL4C-LRE3](conceding, while treating intergeneration justice as a fairness issue, that "[i]ntergenerational fairness could reasonably be treated as an efficiency problem in itself." For example, "justice between generations may be better achieved by intervening in microeconomic transactions that are likely to have an impact on future generations, even if the intervention does not maximize current surplus."). See generally E. PARTRIDGE, ResPONSIBILITIES TO FUTURE GENERATIONS (E. Partridge ed. 1981) (chronicling several essays on the subject of duties to posterity); BAIER, For the Sake of Future Generations, in EARTHBOUND: NEW INTRODUCTORY ESSAYS IN ENVIRONMENTAL ETHICS 214 (J Regan ed. 1984).

62 Moustakas, supra note 39, at 1206.

63 Radin, Market-Inalienability, supra note 45, at 1904.

64 PARTRIDGE, supra note 62, at 10. 
The case of the Parthenon Marbles illustrates these reasons. Though not the result of direct coercion, the appropriation of the Parthenon Marbles by Lord Elgin during the Ottoman occupation took place without direct consultation with the Greeks, the group to which the Marbles belonged as part of their collective cultural heritage. The Greeks were not only disregarded in the decision making process, but were in a constant state of coercion by the Ottoman authorities as a suppressed minority within the Ottoman Empire. One may not plausibly argue that the alienation of the Parthenon Marbles was the product of either free choice or liberty on the part of the concerned group.

The Parthenon Marbles are, by nature, a resource that is nonreplenishable. All property that is alienable shares the same characteristics of interchangeability and substitution by other property of the same market value. As a result, the sharing of property in open market terms never takes the form of a zero-sum game. ${ }^{65} \mathrm{Al}$ ienable property promotes a type of human flourishing that may be achieved through the acquisition of substitute property. The singular nature of cultural property reflects a unique type of communal flourishing so conspicuously derivative of the particular object ${ }^{66}$ that it elevates it into a higher notion of flourishing.

Among the greatest obligations the present owes to the future is to transmit its heritage. ${ }^{67}$ Future generations of Greeks deserve to derive the benefits from the Parthenon Marbles that the earlier generations did. Through alienation of cultural heritage, future generations will disassociate not only from the group they belong to, ${ }^{68}$ but also from its past, threatening the group's existence. ${ }^{69}$ If

65 A zero-sum game "is one in which the payoffs to the players in any outcome add up to zero; what one player gains, the other[s] must necessarily lose." ANDREW COLEMAN, GAME THEORY AND EXPERIMENTAL WORK 47 (1983). Unlike those games, here, there are "prospects for mutually profitable collaboration." Id.

66 See generally John A. Cohan, An Examination of Archaeological Ethics and the Repatriation Movement Respecting Cultural Property (Part Two), 28 ENVIRONS: ENVTL, L. \& POL'Y J. 349, 390 (2004) [https://perma.cc/5UCZ-U7QB].

67 This obligation requires that present generations provide future group members with "a heritage, natural and cultural, that can be valued and enjoyed without absurdity." See MARK SAgOFF, THE ECONOMY OF THE EARTH: PHILOSOPHY, LAW, AND THE ENVIRONMENT 58 (2007) (describing the obligation to pass on cultural heritage to future generations). Cf. Delattre, Rights, Responsibilities, and Future Persons, 82 ETHICs 254, 256 (1972) [https://perma.cc/4ARM-XVWU] ("The meaning of the present depends on the vision of the future as well as the remembrance of the past.").

68 Cf. DERR, The Obligation to the Future, in RESPONSIBILITIES TO FUTURE Generations 37, 39 (E. Partridge ed. 1981) ("Seeking a way to overcome the threat 
we conceptualize society as a "partnership of the dead, the living, and the unborn," 70 the only way to ensure that cultural continuity subsists is through an acceptance of grouphood property inalienability.

Assessing the utility of Radin's theory for cultural property requires an examination of the three necessary particles to its application: (1) the existence of a group and the scope of its claim for inalienability; (2) the answer to why actual possession of a particular object is essential to the preservation of the group's identity; and (3) the determination of what constitutes a fetishistic claim, and if it is applicable to the given object. ${ }^{71}$ This test warrants a case-by-case examination. The following analysis does not constitute a blanket test, but rather a vehicle for investigating the theory's applicability to certain types of cultural property.

\subsection{Grouphood}

In order to determine the applicability of Radin's theory on objects of cultural property, it is essential to comprehend the scope of grouphood as one of the constituent elements for personhood. The notion of a group transcends the picture of a mere collection of individuals into an entity that bears "distinct existence apart from [its] members."72 Equally, the members of the group identify themselves through their membership to it and its assigned personification as well as status quo. ${ }^{73}$ One can find multiple layers of groups, and of groups within groups, interacting among one an-

of death, a man may identify himself with his group, which will outlive him. So he has a real interest in its future well-being").

69 See Radin, Market-Inalienability, supra note 45, at 1902 and accompanying text (quoting J.S. MILL, On Liberty, in THREE ESSAYS 126 (1975)) (“[B]y selling himself for a slave, [a person] abdicates his liberty; he foregoes any future use of it beyond that single act. He therefore defeats, in his own case, the very purpose, which is the justification of allowing him to dispose of himself . . The principle of freedom cannot require that he should be free not to be free. It is not freedom, to be allowed to alienate his freedom.").

70 ROBERT Nisbet, THE QUEST FOR COMMUNITY 25 (1953) (“Mutilate the roots of society and tradition, and the result must inevitably be the isolation of a generation from its heritage, the isolation of individuals from their fellow men, and the creation of the sprawling faceless masses.").

71 T.E. George, Using Customary International Law to Identify Fetishistic Claims to Cultural Property, 80 N.Y.U. L. REV. 1207, 1222 (2005) [https://perma.cc/SS5QWTLL].

72 Owen Fiss, Groups and The Equal Protection Clause, 5 PHIL. \& PUB. AfF. 107, 148 (1976) [https://perma.cc/MBR4-ZT5W].

73 Id. 
other in a plethora of social systems. In questions of cultural property, controversies arise either at an international level among groups of different national cultural heritage, or at a domestic level between a majority group and a minority group representing a singular cultural heritage.

I understand the Greeks as comprising one group, ${ }^{74}$ in a social system of opposing ownership claims seeking restitution of their right to their cultural heritage. Greek "grouphood" has been previously contested by what became known as the "Fallmerayer theory" arguing that today's Greeks are not the biological descendants of the ancient Greeks, in an attempt to establish a disconnect between the two groups. This theory has been attacked both on the grounds of its outdated racialist approach to the issue of cultural continuity, ${ }^{75}$ as well as its simplistic view on culture and identity. The idea that Greek culture has undergone a transformation in the course of its long history through the many and various influences borne upon does not necessarily hinder the continuation of the Greek identity. This has allowed the Greeks to still identify as a people unlike other ancient civilizations that have vanished. ${ }^{76}$ Linguistic continuity represents an earmark of group continuity as historic continuity. The fact that there has been no break in literacy since the Hellenic Greek's adoption of the Phoenician alphabet confirms the strong sense of linguistic heritage and historical continuity between Greek past and present. ${ }^{77}$

The reason why grouphood is of such fundamental importance equating it with personhood is the intrinsic value of cultural groups and their right "to exist, develop, flourish, and perpetuate themselves."78 Group identity generates individual selfperceptions and facilitates an understanding of the world through

\footnotetext{
74 See Evangelos Gr. Avdikos, Continuity, Identity and Folk Studies in Greece, 44 J. OF FOLKLORE 157, 158 (2010), available at http://www.folklore.ee/folklore/vol44/avdikos.pdf [https://perma.cc/JJU9-MPLY] (referring to 'Fallmerayer theory' which argues that today's Greeks are not the biological descendants of the ancient Greeks).

75 See, e.g., S. SALAMONE, HELlENIC NATIONALISM AND GRAECOTURKISH HISTORIOGRAPHY: TOWARDS A THEORY OF CULTURAL SCHISMOGENESIS 24 - 31 (1981) (arguing against the outdated racialist approach to the issue of cultural continuity behind the "Fallmerayer theory").

76 See Moustakas supra note 39, at 1185. (1981).

77 See generally A. TOYNBEE, THE GREEKS AND THEIR HERITAGES 273

78 Moustakas, supra note 39, at 1185.
} 
its prism. ${ }^{79}$ By creating a common culture, 80 a group indirectly influences individual and group behavior within society, 81 and begets a profound sense of social and cultural belonging, as well as a shared collective identity. An individual member of the group develops simultaneously an individual and collective identity through interacting with the group's collective cultural heritage. Cultural property can define grouphood particularly well as it is bound to one's personhood and "speaks directly to the inner consciousness within which we resolve whether we do really feel a sense of belonging to a group or community." 82

By attempting to draw the analogy between personal property and group rights to a collective property, Radin's theory would require an object to be deeply attached to the group's identity so that its separation would be psychologically intolerable to the group, 83 as long as it does not engender fetishistic relations. "The Parthenon has been, and is, for almost all Greeks the symbol par excellence of their national identity, of their links with the past, and of the contribution that they and their forefathers have made to the civilization that we all share." 84 Former Greek Minister of Culture, Melina Mercouri notoriously asserted during her campaign for the return of the Parthenon Marbles: "You must understand what the Parthenon Marbles mean to us. They are our pride. They are our sacrifices. They are a tribute to the democratic philosophy. They are our aspirations and our name. They are the essence of Greek-

79 See DANIEl J. Goldhagen, Hitler's Willing ExeCUTIONERS: ORdinARY GERMANS AND THE HOLOCAUST 33 (1996) (arguing that ordinary Germans were willing executioners in the Holocaust because of the political culture); Kenneth L. Karst, Paths to Belonging: The Constitution and Cultural Identity, 64 N.C. L. REV. 303, 307 (1985-86) [https://perma.cc/M2EL-NAMJ].

80 Kenneth L. Karst, Belonging to America: Equal Citizenship and the CONSTITUTION 21, 309 (1989).

81 See GoldHAGEN, supra note 80 , at 33 .

82 Paul M. Bator, An Essay on the International Trade in Art, 34 STAN. L. Rev. 275, 305 (1982) [https://perma.cc/GEP8-922R] ("The existence and awareness of a common artistic heritage can make a powerful contribution to the consciousness of the relationship between self and community").

83 R. Browning, The Case for the Return of the Parthenon Marbles, 36 MusEum 38 (1984) (quoting the Director-General of UNESCO), reprinted in J. MERRYMAN \& A. ELSEN, LAW, ETHICS AND THE VisuAL ARTS 135 (5th ed. 1979).

84 Christopher Hitchens, The Elgin MARbles: SHOuld TheY Be Returned to GREECE 25 (1987) (claiming that the Marbles are essential to Greek identity because they "tell [Greeks] who [they] are and where [they] came from."). See Elsen, Introduction: Why Do We Care About Art?, 27 Hastings L. J. 951, 952 (1976) [https://perma.cc/3AGP-J465] (explaining the significance of the Parthenon Marbles to modern day Greeks). 
ness." 85 Adding to this special significance the Parthenon Marbles hold for Greek identity, Melina Mercouri had suggested elsewhere:

Because when we are born, they talk to us about all this great history that makes Greekness [. . .] We do not ask to have statues and paintings and everything that is Greek in all the museums of the world. But with the Parthenon Marbles it is a question of restoring integrity to a mutilated building. The Parthenon has stood for 2,000 years, symbol of a civilization. We want the most beautiful part of it back in Greece. ${ }^{86}$

A possible appropriation of the Statue of Liberty would arguably shatter the bond shared by Americans and their ancestors, who first experienced the same first glimpse of the United States in order to pursue the American dream. Similarly, Lord Elgin's removal of the Marbles from the Parthenon has injured Greek grouphood as though destroying the "Greeks manna," 87 the embodiment and highest celebration of "being Greek." 88 The selectivity of the return claim for the Parthenon Marbles vis-a-vis the countless Greek antiquities found in museums around the world, in conjunction with the elevation of the Parthenon Marbles as the ultimate representation of Greek identity, exemplify the extent to which they are bound to Greek grouphood. What remains to be established is

\footnotetext{
85 Melina's Speech to the Oxford Union, HeLlENIC ElECTRONIC CENTER, (quoting transcript of Melina Mercouri's speech from Jun. 1986), http://www.greece.org/parthenon/marbles/speech.htm.

86 QEA: Melina Mercouri: Greece's Claim to the Elgin Marbles, N.Y. TIMES, Mar. 4, 1984, available at http://www.nytimes.com/1984/03/04/weekinreview/q-a-melinamercourt-greece-s-claim-to-the-elgin-marbles.html [https://perma.cc/Q3Z9-4NA4].

87 " [I]f art gives an aura of prestige to a city or a dynasty, rival cities or rival dynasties, which set out to conquer and humble them, will seek also to destroy their "myth" by depriving them of this aura and appropriating it to themselves, like cannibals who, by devouring parts of their enemies, think to acquire their mana, the intangible source of their strength." H. TREVOR-ROPER, THE PLUNDER OF the Arts In the SEVEnTEeth Century 7 - 8 (1970), reprinted in J. Merryman \& A. ElsEN, LAW, ETHICS AND THE Visual ARTs 54 (5th ed. Kluwer Law International) (1979).

88 Garet uses the term "communality" instead of grouphood. He views communality (my grouphood) as an intrinsic structure of existence along with individuality and sociality. R. Garet, Communality and Existence: The Rights of Groups, 56 S. CAL. L. REV. 1001, 1015 (1983) [https://perma.cc/H2WD-WPPE]. With each of these structures he associates a characterizing emotion: for individuality, dread; for sociality, hope; and for communality, celebration.
} 
whether the relationship between the object and the group bears any fetishistic quality.

\subsection{A Non-Fetishistic Claim}

Radin's theory suggests that in order to establish inalienability, the retention of property must not promote "bad object relations." Radin leaves us with a rather intuitive test in determining the existence of such a dynamic. In order to make a determination, it is necessary to distinguish between good and bad object relations. Irrespective of the level of attachment between an object and a group, there is an equal need for an objective moral consensus rendering that relationship compatible with personhood. Radin defines good object relations as those that are healthy, and bad object relations as those that are fetishistic. 89 The test that property needs to pass is whether it promotes good object relations or, at de minimis, does not constitute bad object relations.

In the group context, good object relations exist when the retention of cultural property fosters important values of the group as well as enhances its education, community, and collective identity. On the other hand, retention of an object for the sole purpose of preventing others from having it, along with objects that promote animosity, cultural intolerance, and feelings of hostility on the part of the group, could plausibly constitute fetishistic qualities. ${ }^{90}$ The Greek claim over the Parthenon Marbles, unlikely reflects bad object relations. The Greek claim ${ }^{91}$ does not portray a desire to hoard antiquities in Greece or to be overly materialistic. The reasons reflect a desire for reunification of the Parthenon Marbles with their counterparts; they are an accentuation of Greek identity and pride, a reminiscence of the past, and a sense of continuation of the Greek

89 See Radin, supra note 9, at 968 (stating that society should discourage bad object relations because "becoming too enthralled with property takes away time and energy needed to develop other faculties constitutive of personhood."); Dummett, The Ethics of Cultural Property, ATHENA, at 318, Oct. 1986 , (arguing that anyone who relishes cultural diversity should find local patriotism endearing and its affects admirable; "as with other loyalties, it would become malign only if it were to engender contempt for or hatred of other localities.").

90 See Dummett, supra note 90 , at 318.

91 See Bator, supra note 83, at 285 (arguing that Greece does not desire objects other than those to which it has a rightful legal claim and that are inseparable from its history and culture). 
community into the present and future. Such claims not only depart from any fetishistic connotation but, a fortiori, establish conditions that foster and promote good object relations.

An interesting antithesis could be drawn with the British claim. Radin suggests that when property is bound up with the identity of multiple claimants, it is enough for one of the claimants to have a fetishistic attachment to the object in order for the claim to fail. ${ }^{92}$ One of the reasons why Britain insists on retaining the Parthenon Marbles is that they consider the Parthenon Marbles to have formed part of their cultural heritage through the years. ${ }^{93}$ The circumstances of the acquisition of the Parthenon Marbles in combination with their frequent portrayal as the forefront of British cultural imperialism could render the British relation to them fetishistic. Of course, the Parthenon Marbles present a relatively weak case for such an argument, which could, to its truest form, be exemplified in the context of the British overseas conquests or the German Nazi looting. ${ }^{94}$ Nevertheless, it represents a view that only bolsters the Greek case. After all, the inalienability of the Parthenon Marbles is to be determined by their original source, rendering any concurrent British claim moot.

\section{CUltural NATIONALiSM \& CULTURAL INTERNATIONALISM}

Most scholars have attempted to map the arguments raised by Greece and Britain regarding the Parthenon Marbles under the division of "cultural nationalism" and "cultural internationalism." 95

92 See Radin, Property and Personhood, supra note 9, at 969 (arguing that a party's ownership claim over an object with multiple claimants should fail if they have a fetishistic attachment to the object).

93 See infra Part IV (discussing Britain's claim on why the country has a right to the Parthenon Marbles).

94 See George, supra note 72, at 1235 (likening the scope of the Parthenon Marbles issue to German Nazi looting).

95 Professor Merryman coined these two terms to describe the dichotomous views of cultural property, the former viewing such property "as part of a national cultural heritage," the latter "as components of a common human culture." John H. Merryman, Two Ways of Thinking About Cultural Property, 80 AM. J. INT'L L. 831, 831 - 32 (1986) [https://perma.cc/ZV4T-SV6E] [hereinafter Merryman, Two Ways of Thinking]. These terms have been widely accepted and used in subsequent scholarship on the subject of cultural property to embody the two schools of thought in the debate. See infra notes 161 - 164 and accompanying text (arguing that Merryman's three principles of cultural internationalism-preservation, integrity, and distribution-are primarily property concepts, any internationalist aspect 
These two categories provide a certain taxonomy within the field by aggregating arguments into what has become not only a debate of semantic importance, but also of qualitative association. The argument over the Parthenon Marbles has transcended from being a contention of ownership to epitomizing the perennial conflict between nationalism and internationalism as sociopolitical conceptions, and ethical ideals. This is evident when claims against cultural nationalism take the form of hoarding accusations and cosmopolitan ethical veneers; ${ }^{96}$ similarly, claims against cultural internationalism induce arguments of human rights violations and museum imperialism. ${ }^{97}$ The next part discusses these two concepts and argues for their deconstruction in order to facilitate solutions instead of the perpetuation of stale debate.

\subsection{Cultural Nationalism}

Source nations with rich cultural heritage most often echo cultural nationalist arguments. ${ }^{98}$ This is because cultural property is often vested with emotional qualities that bind it to the group's identity. The elements encompassed in Radin's theory advocating for the inalienability of certain cultural property translate into an irreparable loss when removed from the group of origin, rendering the restoration of the status quo ante through a return as the only means for relief.

The doctrine of nationalism ${ }^{99}$ emerged in Europe during the French Revolution, is rooted in the Enlightenment period, and re-

being a secondary consideration, and that his cultural nationalism arguments emphasize the cultural aspect and are only nationalist in that they depend on the cultural bond between an object and a particular community or nation).

96 KWAME ANTHONY ApPiaH, COSMOPOLITANism: Ethics in a World of STRANGERS 135 (W.W. Norton eds., 2007).

97 M.L. McIntosh, Exploring Machu Picchu: An Analysis of the Legal and Ethical Issues Surrounding the Repatriation of Cultural Property, 17 DUKE J. COMP. \& INT'L L. 199, 210 (2006). (1996).

98 Michael Richardson, Revived Self-Identity Spurs Art Sales, INT'L HERALD TRIB.

99 John Henry Merryman, Retention of Cultural Property, 21 U.C. DAVIS L. REV. 477, 490 (1987-88) (citing Elie KedOURIE, NATIONALISM (Wiley 1961)) (defining the doctrine of nationalism as dividing humanity into separate and distinct nations, claims that such nations must constitute sovereign states, and asserts that the members of a nation reach freedom and fulfillment by cultivating the peculiar identity of their own nation and by sinking their own persons in the greater whole of the nation.). 
flects the role of new sovereign nations as primary actors in global affairs. 100 English and German romanticism influenced the perceptions of nationalism in the field of cultural property generating retention schemes and a sense of belonging within a nation's cultural as well as physical boundaries. ${ }^{101}$ When retention is impossible due to prior alienation of cultural objects, cultural nationalism advocates a return to the source country. This school of thought dominated the post-1970 era with multiple international treaties and enacted national statues ${ }^{102}$ acknowledging its legitimacy. ${ }^{103}$ The traditional arguments for return of the Parthenon Marbles are largely based on notions of cultural nationalism. ${ }^{104}$

Unfortunately, the emotional and romantic components of cultural nationalism make it equally susceptible to indeterminate appeals. These carry politicized elements with no clear correspondence to cultural property, such as notions of human rights violations, imperialism, and post-colonial self-determination. While it is understood why certain objects of cultural heritage may have an emblematic quality, they oftentimes get mixed with assertions of national autonomy and sovereignty. 105 It is true that the Greek politician to achieve the return of the Parthenon Marbles would immediately become a national hero. This is evidence of the fact that cultural nationalism bears astute political significance and is capable of creating political loss and benefit-something that makes it inherently vulnerable to ephemeral campaigns, thespian political maneuvers, and, perhaps most importantly, political risk.

Despite the weaknesses of cultural nationalism both in its normative standpoint and in return strategies, it raises important arguments for cultural property. Cultural nationalism stands for everything a theory of property for grouphood would stand for, on a larger scale. But while Radin's theory would only raise certain pieces of cultural heritage to the level of inalienability, cultural nationalism would advance the return of all objects of cultural property to their source nation. Admittedly, such a depiction of cultural nationalism represents its maximum level of application, but

\footnotetext{
$100 \quad$ Id.

101 Id. at $494-95$.

102 Id. at $487-89$.

103 See UNESCO Convention 1970, supra note 6 (exemplifying this ideology). bles).

104 See supra Part I (outlining arguments for the return of the Parthenon Mar-

105 Claudia Caruthers, International Cultural Property: Another Tragedy of the Commons, 7 PAC. RIM. L. \& POL'y J. 144, 156 (1998).
} 
also encompasses all other intermediate stages of individual, partial, and full return of cultural property.

\subsection{Cultural Internationalism}

Cultural internationalism takes a global view on property perceiving cultural objects as belonging to all mankind, ${ }^{106}$ regardless of their place of origin. ${ }^{107}$ Merryman proposes three principles that define cultural internationalism: preservation, integrity, and access. These principles represent a scale for weighing the appropriate allocation of cultural property in the event of ownership contestation, when moral and legal arguments are equalized. 108 Preservation is used as a justification of removal from a country of origin and retention by the country of possession. In the example of the Parthenon Marbles, there is no indication that they would be better preserved in London over Athens, or vice versa. As always, inertia tends to favor the status quo and the argument of preservation would either land flat on either party, or favor repose. Integrity of the cultural item, on the other hand, advocates for restitution of cultural objects when they bolster the original integrity of the monument they form a part of. The argument of integrity would favor Greece for the reinstallation of the Parthenon Marbles on the Parthenon allowing for a unification of the monument. 109 Despite the fact that this reintegration would expose the Parthenon Marbles to naturally damaging open air conditions, a return of the Parthenon Marbles to the Acropolis Museum would still favor an integrity argument based on proximity only second best to the original. ${ }^{110}$

106 See 1954 Hague Convention, supra note 2 (explaining the global view that cultural property belongs to all people as a whole, not just those in its country of origin).

107 Merryman, Two Ways of Thinking, supra note 96, at 831.

108 Even if this situation does not go beyond the realm of a hypothetical, where neither the source nor the acquiring nation has the stronger claim, it is doubtful whether moral and legal arguments may ever be equalized without running into a problem of incommensurable values.

109 See MERrymAN, supra note 14, at 1918 (explaining that returning the Parthenon Marbles to Greece would allow for the original monument to be unified more completely, which is preferable to leaving them in Britain).

110 Christopher Hitchens highlights this point by drawing a comparison between the Parthenon Marbles and other famous works of art "it is wrong that a brilliant frieze, which was carved as a unity, and tells a narrative story, should be 
The third principle of access reinforces the idea of cultural property belonging to all mankind: cultural property should be made accessible to all people. Proponents of cultural internationalism suggest that access favors the British argument, as a potential return of the Parthenon Marbles would lead to a cultural deficit of Britain. ${ }^{111}$ However, this argument ignores other ways of arrangement, which would maintain access to Greek cultural property in both Britain and Greece, while returning the Parthenon Marbles to their source. Such arrangements can be made, inter alia, through negotiated loans, exchanges, or joint trusteeship, which will be further explored in Part IV. Internationalists also argue that the display of cultural property outside of its original boarders serves an ambassadorial function, exposing other cultures to its own, educating, and increasing awareness. ${ }^{112}$ Though this is certainly an important function and a critical point, it is not antithetical to the return of the Parthenon Marbles as long as the British Museum is able to provide its visitors with equal exposure to the ancient Greek culture of the golden age through installations of similar caliber.

While cultural internationalism contains some idealistic appeal, it runs into equally politicized issues with cultural nationalism. The idea of cultural heritage of "all mankind" has been argued to translate unilaterally into the wealthy nations and their citizenry. ${ }^{113}$ Cultural internationalism has often been equated with an expression of neo-libertarian rationalism that is only concerned with market determinations and is espoused by museums and collectors of wealthy market nations. ${ }^{114}$ Cultural internationalists are often charged with double standards and a Eurocentric as opposed to

broken in two and exhibited in separate cities. Suppose that the Mona Lisa had been arbitrarily sawn in two, with one half in a gallery in Budapest and the other in Barcelona. Who would resist the call to reunite the two parts?" Christopher Hitchens, Who Really Owns Culture, THE InDEPENDENT, 17 (Nov. 22, 1999). See also GREENFIELD, supra note 12, at 73.

111 See MERryman, supra note 14, at 1919 (noting that returning the Parthenon Marbles to Greece would lead to a cultural loss for Britain).

112 See McIntosh, supra note 98, at 211 (explaining the notion that displaying cultural objects in countries other than its origin is positive because it educates and makes people outside of the home country aware of the history relating to the object).

113 See generally SAlly Price, Primitive ART IN Civilized Places (1991), especially Chapter 2 (discussing who the lucky recipients and who the unlucky bestowers of these kinds of "gifts" are).

114 C. Caruthers, International Cultural Property: Another Tragedy of the Commons, 7(1) PACIFIC RIM L. \& POL'y J. 143, 155 (1998). 
truly global sense of "cosmopolitanism." We see that both cultural nationalism and internationalism carry political connotations and cease to represent the original mechanical ordination they sought to facilitate.

\subsection{An Integrated Solution}

One of the most interesting arguments within the debate between cultural nationalism and internationalism is that of the British government that the British Museum ought to retain the Parthenon Marbles because they have become part of the British cultural heritage due to their presence in Britain for more than a century. ${ }^{115}$ Though this time-tied argument pales in comparison to that of the Greeks, who were in possession of the marbles for nearly 2500 years, 116 its intrigue lies in its cultural nationalist quality. Some of the Greek arguments also rise to the level of cultural internationalism. This is the very epistemological problem of the division between cultural nationalism and internationalism - an overlap that would not only blur the distinction, but also convey that it may cause more problems than it claims to solve. 117

Recent scholarship supports the premise that cultural internationalism bears moral primacy over cultural nationalism. Such an idea presumes that cultural nationalism and internationalism are necessarily distinct and in isolation from one another, and that they cannot co-exist. Cultural nationalism has been advanced and is sometimes manipulated to project erroneous sentiments and dramatized assumptions without truly exploring the deeper significance and importance of cultural property returns. The relevance of cultural nationalism does not lie as much on nebulous concepts of national pride and accumulation of collective sentiment as it does on the need for cultural revitalization. What is profoundly

115 See Merryman, supra note 14, at 1915 (describing the British claim that the "Elgin Marbles and other works in the British Museum have entered British culture, help define the British to themselves, inspire British arts, give Britons identity and community, civilize and enrich British life, and stimulate British scholarship").

116 M.J. Repas, The Deflowering of the Parthenon: A Legal and Moral Analysis on Why the 'Elgin Marbles' Must be Returned to Greece, 9 InTELl. Prop., Media And EnT. L. 911, 931-32 (1999). point.

117 See infra at Part IV (C) of this article for a more elaborate discussion of this 
important is the perpetuation of unique historical qualities and dispositions that are necessary for linking the past with the ensuing future of mankind. Though such purpose may, at first, appear fully in line with cultural internationalism, the recreation and reawakening of cultural past would be marginally impossible in a world dominated by cultural internationalism.

In a world of asymmetric power, cultural internationalism jeopardizes the subsistence of weaker cultures against dominant ones through socio-cultural assimilation in the long run.118 Without the input of distinct cultural entities, the global cultural kaleidoscope would eventually be impoverished and subjugated to the dominant culture. Though such a future may be alluring for certain cosmopolitan theories, its de facto effect would directly contravene the noblest ideas behind cultural internationalism of a "global" human flourishing through cultural sharing and education. The exchange of cultural objects is certainly in line with the spirit of cross-cultural fertilization and cooperation. But no one would be comfortable with a nation's self-proclaimed deprivation of its past under the idea that cultural internationalism supports its possession by another entity because it now forms part of an international civilization. Though cultural internationalism is tremendously important, it should also be guided by restrictions in its application contrived by cultural nationalism.

Our central inquiry should not be whether cultural nationalism and internationalism are mutually exclusive but rather their potential to peacefully coexist. ${ }^{119}$ I argue that the two worlds can do so under clarified objectives that do not mesh with each other's agendas but instead bolster one another. Cultural nationalism will facilitate bringing to light forgotten cultural characteristics while cultural internationalism will disseminate them in order to enhance our knowledge and understanding. Neither movement needs to subsume the other. Instead, they can be combined within a carefully coordinated framework that supports both their agendas and most effectively satisfies the parties through propagating past cultures and civilizations.

118 S. Ghoshray, Repatriation of the Kohinoor Diamond: Expanding the Legal Paradigm for Cultural Heritage, 31 FORDHAM INT'L L.J. 741, 757 (2007) [https://perma.cc/S8TB-V26R].

119 Id. at 758. 


\section{A NeW RetURn StRATEgy For GREECE}

\subsection{Successful Returns}

Over the past two decades, the number of incidents involving the return of cultural artifacts to source nations from museums, governments, and individual collectors has increased internationally. In an effort to advance an integrated spirit of cultural nationalism/internationalism, we must examine best practices of states that claim the return of cultural property, or that retain their right to its exposure. Most successful past stories of returns have involved voluntary returns by governments, museums, and individuals. ${ }^{120}$ Examining the details of every successful return is empirically intriguing in order to improve return rates in the future. It would allow one to draw linkages and find common denominators that lead to a factoring of circumstances yielding to returns. But the existing sample is too scanty and diverse to facilitate general conclusions, and the information that is provided for the backstage of most return agreements is scarce. I have thus handpicked some of the successful returns that fit within the Parthenon Marbles claim. Their examination will facilitate building a new comprehensive strategy for Greece in pursuing the return of the Parthenon Marbles.

Greece has followed, in part, the lead of Italy in becoming more aggressive about its pursued pieces of cultural heritage. Recently, Greece claimed a small victory by successfully negotiating the return of a votive relief and tombstone by the J. Paul Getty Museum in California. ${ }^{121}$ After nearly a decade of diplomatic efforts between the J. Paul Getty and the Greek Ministry of Culture, Greece announced that it had decided to take legal action against the J. Paul Getty for purchasing and displaying looted objects of Greek

120 See M.J. Reppas, Museums' Trophy Cases of Their Looted Treasures and Return Stolen Property to the Countries of Origin and the Rightful Heirs of Those Wrongfully Dispossessed, 36 DENVER L. INT'L L. \& POL'Y 93, 113 (2007) [https://perma.cc/73Y8-6MND] (providing many examples of this recent phenomenon).

121 Hugh Eakin, Getty Museum Agrees to Return Two Antiquities to Greece, NY TIMES, Jul. 11, 2006, at E1 [https://perma.cc/9KS7-4D7Z]; Nicholas Paphitis, Getty Museum to Return 2 Greek Treasures, USA TODAY, Dec. 11, 2006, http://usatoday30.usatoday.com/tech/science/2006-12-11-getty-greece_x.html [https://perma.cc/9KS7-4D7Z]. 
origin. ${ }^{122}$ This turned out to be the key move in getting the J. Paul Getty back to the negotiating table, this time with open streams of communication. The J. Paul Getty's director Michael Brand has been presented as extremely cooperative in reaching a compromise with Greece ${ }^{123}$ despite suggestions that "there is no hard evidence of an unlawful excavation." 124 Michael Brand has also pleaded that he will recommend the return of other antiquities in the future; 125 testament of what could be a new approach of the J. Paul Getty towards return claims.

The University of Heidelberg returned a piece of the Parthenon's north frieze to Greece "in recognition of the significance of the Parthenon as part of the world's cultural heritage."126 The Greek Ministry of Culture secured a donation of a piece to replace it in the University's collection "in accordance with the current international practice."127 Greece has been actively employing a strategy that for every piece of the Parthenon returned a goodwill counter donation of another antiquity will follow. 128

In November 2006 a piece of the Erectheion was returned to Greece by a Swedish national whose uncle had taken the piece from the Acropolis when he served as an officer of the Swedish Navy in 1895.129 The benefactor stated, "[she] could not keep what rightly belonged to the Greek people in good conscience." 130 The Greek Ministry of Culture appraised the voluntary individual re-

122 Ralph Frammolino and Jason Felch, Greece Vows Legal Action Against Getty, L.A. TIMES, Nov. 23, 2005, at A10 [https://perma.cc/2NPP-HVGQ].

123 See Eakin, supra note 122, at E1 (providing favorable treatment to Brand and the Getty Museum despite a sympathetic treatment of the Greek claims); Paphitis, supra note 122.

124 Eakin, supra note 122, at E1.

125 Id.

126 Press Release, University of Heidelberg Fragment of Parthenon Sculptures to Greece Permanently, UNIV. OF HeIDELberG, Jan. 11, 2006, available at http://www.uni-heidelberg.de/press/news/news06/2601par_e.html [https://perma.cc/N83K-XC6Q].

127 See id. (demonstrating Greece's approach in repatriating its lost artifacts).

128 Christy Papadopoulou, Parthenon Fragment Returns Home, ATHENS NEWS,

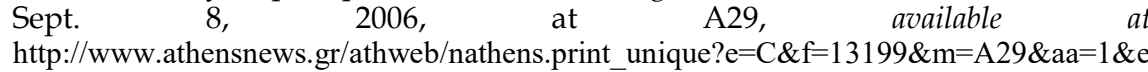
idos=A [https://perma.cc/QGV6-G2MS].

129 Sweden to Return Acropolis Frieze to Greece, Blouin ArTinfo, Mar. 5, 2007, http://www.blouinartinfo.com/news/story/267450/sweden-to-return-acropolis-frieze-togreece [https:/ / perma.cc/8EA6-NDWT].

130 Helena Smith, Missing Their Marbles, NEWSTATESMEN, Oct. 23, 2006, available at http://www.newstatesman.com/node/195629 [https://perma.cc/NGN7-4N55]. 
turn by stating that "the restitution of even the smallest fragment from the Parthenon and the Acropolis in general is of the highest value to us." 131

Greece has been actively pursuing the return of cultural objects attached to the Parthenon under emotional appeals and through setting a quid pro quo customary usage. Both practices carry important merit individually and collectively in procuring results, yet they seem to have not fully convinced the most important player in the negotiation, the British Museum, and by extension the British government, to take the possibility of the Parthenon Marbles return seriously. The question remains as to what further methods the Greek government could employ in order to convince the British that a return of the Parthenon Marbles would be in their shared interest.

\subsection{Loan Strategy - The Euphronios Krater}

Short and long term loans are a common option in successful returns of cultural artifacts. When transfer of title is undesirable or impossible due to legal caveats, parties may be more comfortable to agree to loan the object whose return is requested. Conversely, they may agree on returns in exchange for a loan or series of loans to the party from which they are claimed.132 Agreement on such grounds is usually reached after a lengthy process of negotiation between the parties. A particularly instructive example of a style of negotiation is the one pursued by Italy towards the Boston Museum of Fine Arts, the Metropolitan Museum of Art in New York, and the J. Paul Getty Museum in California. The only agreement among the three that has been published and may serve as an illuminating source of a successful return claim is the agreement between Italy and the Metropolitan Museum of Art. ${ }^{133}$

131 Nicholas Paphitis, Swedish Woman Returns Acropolis Artifact to Greece, CBC NEWS, Nov. 17, 2006, http://www.cbc.ca/m/touch/arts/story/1.624384 [https://perma.cc/ V32K-X8Y9].

132 Marie Cornu \& Marc-André Renold, New Developments in the Restitution of Cultural Property: Alternative Means of Dispute Resolution, 17 INT'L J. CUlT. Prop. 1, 20 (2010) [https://perma.cc/PSV9-BUX2].

133 Agreement between the Ministry of Cultural Assets and Activities of the Italian Republic and The Metropolitan Museum of Art, (Feb. 21, 2006), reprinted in 13 INT'L J. CUlt. PROP. 427 (2006) [https://perma.cc/UN49-FDBG] [hereinafter ItalyMetropolitan Museum Agreement]. 
The agreement epitomizes a spirit of cooperation within a broader framework agreed between the two parties. It involved the return of several cultural artifacts, the most notorious among them being the Euphronios Krater. While most legal scholars had contended à propos that Italy's return claim was legally weak, ${ }^{134}$ negotiations led to an unexpected agreement with the Metropolitan Museum reflecting a careful balance of cultural nationalism and internationalism. ${ }^{135}$ The bilateral agreement has four important elements: (1) the transfer of ownership of the artifacts to Italy; 136 (2) the liability waiver on behalf of the Metropolitan Museum;137 (3) the establishment of a cooperative framework between the parties on the basis of exchanges and loans; 138 and (4) the promotion of research and education through exclusive excavations and education of museum personnel. Italy agreed "to make possible the continued presence in the galleries of the Museum of cultural assets of equal beauty and historical and cultural significance to that of the Euphronios Krater."139 In order to satisfy this provision, Italy will make four-year loans to the Metropolitan Museum on a continuing and rotating basis of several pre-agreed cultural artifacts. ${ }^{140}$ The agreement also sets out a detailed scheme for loans of items discovered during excavations in Italy, financed or restored by the Metropolitan Museum. ${ }^{141}$ The span of the agreement is long, since it will remain in force for forty years ${ }^{142}$ with a possibility of renewal upon agreement between the parties. ${ }^{143}$

The negotiation strategy that is reflected in the agreement be-

134 Under American law, Italy would have to argue that the Met knowingly purchased stolen antiquities - a difficult burden to meet given these circumstances. See, e.g., United States v. Schultz, 333 F.3d 393, 411 (2d Cir. 2003) [https://perma.cc/JRX8-ULBF] (interpreting the National Stolen Property Act), 18 U.S.C. § 2315 (2006); United States v. McClain, 545 F.2d 988, 993 - 94 (5th Cir. 1977) [https://perma.cc/6TUC-JTTF].

135 See Italy-Metropolitan Museum Agreement, supra note 134, at 427 (outlining Italy's national interests in recovering the artifacts).

136 Id. at 428.

137 See id. at 433 (clarifying that the Agreement waives any liability that the Metropolitan Museum might have due to their possession of the Italian artifacts).

138 See id. at 430 (setting forth the four year loan structure of the Agreement).

139 Id.

140 Italy-Metropolitan Museum Agreement, supra note 135, at 430.

141 Id.

142 Id.

143 See id. at 433 (clarifying that the terms of the loan are the maximum which is allowed under Italian law and that the loan is renewable). 
tween Italy and the Metropolitan Museum presents a unique case for drawing possible analogies in drafting a new strategy for Greece. The underlying method of this particular agreement is that it is not reflective of a one-shot game coordination tactic. Instead, by establishing possible repeated games, it allows for a relationship building potential that far outweighs the bargaining leverage of the individual quid pro quo strategies that Greece has pursued thus far.

\subsection{A New Negotiation Strategy for Greece}

Negotiation is arguably the better strategy in instances where a country does not have a strong legal claim, or where the parties would benefit from forming long-term bonds with each other. Though claims resting on sentimental and ethical arguments are pervasive, they rarely succeed when unaccompanied by a balancing of the cultural nationalist and internationalist arguments in order to strike an alluring deal satisfying both sides. In the case of the Parthenon Marbles, despite the internationally strong support for their return, the British Museum has remained adamant in its retention policy. I argue that aside from the legal and moral arguments advanced for decades, the key to initiating a constructive negotiation is to establish concrete examples of how the return of the Parthenon Marbles would benefit not only Greece but also the British Museum and the international art community as a whole.

The bilateral agreement of Italy and the Metropolitan Museum of Art is instructive in highlighting the importance associated with the true forms of cultural internationalism: public access, education, and international cooperation in cultural exchange. ${ }^{144}$ This is a critical element of a current and relevant return strategy that Greece has not yet fully embraced and addressed. As Philippe de Montebello, the Director of the Metropolitan Museum, strikingly notes, the bilateral agreement "pave[d] the road to new legal and ethical norms in the future" while "not depriv[ing] the millions of visitors to our museum of the opportunity to see archaeological material." 145

144 Paige S. Goodwin, Mapping the Limits of Repatriable Cultural Heritage: A Case Study of Stolen Flemish Art in French Museums, 157 U. PA. L. REV. 673, 691 (2008) [https://perma.cc/UB4X-WQNV].

145 Elisabetta Povoledo, Italy and U.S. Sign Antiquities Accord, N.Y. TIMES, Feb 22, 2006, at E7 [https://perma.cc/Y6AU-EXQC]. 
Aaron Kyle Briggs has also pointed to the instructive nature of the bilateral agreement by suggesting that it was successful because it cumulatively met five crucial points: the art in question was important to the Metropolitan Museum; the Metropolitan Museum did not want to enter a lengthy litigation; Italy is an art-rich nation whose cultural property is of high-demand in the international art world; Italy is capable of preserving the objects if returned; and Italy had some form of evidence pointing to the illegality of the original acquisition by the museum. ${ }^{146}$ Italy has also implemented a carrot and stick approach to increase its bargaining power by refusing to lend cultural artifacts to uncooperative museums for temporary exhibition, while agreeing to a liability waiver model in exchange for return of cultural property. ${ }^{147}$ The bilateral agreement between Italy and the Metropolitan Museum provides a close to ideal framework for future return negotiations through combining elements of morality, legality, and the true forms of cultural nationalism and internationalism. These elements constitute sine qua non pieces in a potential successful negotiation strategy puzzle.

A negotiation model based on the bilateral agreement for the Parthenon Marbles would first give Greece the opportunity to present its case on why it considers that the acquisition of the Parthenon Marbles bore elements of illegality. Though arguments on the legality of Lord Elgin's actions have been thoroughly examined by both sides, it is important for the negotiating parties to start afresh without clinging on the bias of the past. Both sides of the debate may advance legal arguments. But what is truly important to acknowledge is that litigation on the legality of Lord Elgin's acts before a British or International Court would constitute a binding legal precedent over the parties. A potential legal precedent favoring Greece would not only be menacing for the British Museum but also for the ideas of cultural property internationalism and cosmopolitanism. Such a development should be undesirable not in that it would constitute an unjust result, but in its potential spillover and domino effects. Legal precedents able to fuel national claims and susceptible to political benefit manipulations would

146 See Aaron K. Briggs, Consequences of the Met-Italy Accord for the International Restitution of Cultural Property, 7 CHI. J. INT'L L. 623, 652 - 53 (2007) [https://perma.cc/T5MU-W6KK] (suggesting that the Accord may open new avenues for dialogue about art and ownership).

147 See id. (suggesting that the Accord may open new avenues for dialogue about art and ownership). 
only shatter the desired framework to produce the type of intercultural fertilization necessary for the progress of mankind. It is not the factual precedent of a potential Parthenon Marbles return that should alarm the British and the international art community for a "slippery slope" effect, but the establishment of a legally binding precedent.

Potential legal claims should only be discussed if one of the parties refuses to go to the negotiation table by virtue of what it considers to be a stronger legal claim. Parties though should advance legal claims not as threatening leverage, but as an indication of what could be avoided through engaging in a negotiation, instead of lengthy legal proceedings responsible of incurring unnecessary costs and dubious outcomes. Upon reaching the negotiation table, what is necessary is a systematization of the process under a negotiation model that will facilitate solutions and transpire the walls built by the parties.

The negotiation model that I use in order to analyze a step-bystep negotiation on the Parthenon Marbles is Stuart Diamond's Four Quadrant Negotiation Model. ${ }^{148}$ The Four Quadrant Negotiation Model is a goal-oriented model based on strategies involving the acknowledgment that people are essential to the negotiation, favoring credibility, trust, standards, and an incremental outlook. When it comes to issues of public concern, Diamond suggests the following questions in evaluating the quality of a negotiation that is critical to its success:

How effective is the communication between the parties? Do the parties find, understand, and consider one another's perceptions? Is the attitude one of forcing the other party's will or of collaboration? Do the parties blame each other for yesterday, or value them for tomorrow? Are the respective needs of each party uncovered and traded? Is the action incremental or do parties try to do everything at once? Are the parties taking actions that meet their goals? How high is the emotional level? Do the parties try to be dispassionate? Do the parties use one another's standards in reaching a decision? Is there a problem-solving process in which differences

148 For an elaborate discussion and analysis of the Four Quadrant Negotiation Model, see Stuart Diamond, Getting More: How to Negotiate and Achieve YOUR GOALS IN THE REAL WORLD (2010). 
are valued?149

A quick glimpse at this set of questions describes most of what has arguably gone wrong in the negotiation between Greece and the British Museum over the Parthenon Marbles. Instead of reflecting on the past and reviewing how the actions of the parties have been detrimental to the development of a satisfactory solution, I will briefly analyze the Four Quadrant Model in an effort to escape the old negotiation practices. I will address the negotiation as part of the Greek side arguing for the return of the Parthenon Marbles. The following analysis is by no means authoritative. On the contrary, it utilizes pieces of argumentation that have been brought up within scholarship, public official statements, press releases, and anecdotal experience. It is intended to serve merely as a general paradigm to what a different negotiation strategy would look like and offer.

\section{FOUR QUADRANT NEGOTIATION MODEL ANALYSIS}

\begin{tabular}{|c|c|}
\hline $\begin{array}{l}\text { QUADRANT I - PROBLEMS \& } \\
\text { GOALS }\end{array}$ & $\begin{array}{c}\text { QUADRANT II - SITUATION } \\
\text { ANALYSIS }\end{array}$ \\
\hline $\begin{array}{l}\text { 1. GOALS: } \\
\text { A) Short term: The establish- } \\
\text { ment of a cooperation framework } \\
\text { with the British Museum fostering } \\
\text { cultural exchange; } \\
\text { B) Long term: The return of the } \\
\text { Parthenon Marbles of the British } \\
\text { Museum Collection to the Acropo- } \\
\text { lis Museum. }\end{array}$ & $\begin{array}{l}\text { 6. NEEDS/INTERESTS: } \\
\text { A) Rational: Restitution, politi- } \\
\text { cal benefit, cultural integrity } \\
\text { (shared), economic revenue } \\
\text { (shared), conservation of cultural } \\
\text { property (shared); } \\
\text { B) Emotional: Restitution of na- } \\
\text { tional pride, celebration of the } \\
\text { Greek identity, trust (shared), not } \\
\text { being perceived as making unnec- } \\
\text { essary/unreasonable concessions } \\
\text { (shared), ownership (conflicting); } \\
\text { C) Unequally Valued: econom- } \\
\text { ic revenue, national pride, owner- } \\
\text { ship }\end{array}$ \\
\hline
\end{tabular}

149 See id., at 347 (explaining the framework by which the quality of a negotiation can be determined using his model). 
2. PROBLEMS:

A) The issue is too politicized and striking a balance that would not incur significant political loss is delicate;

B) The issue naturally springs a lot of emotion.

\section{PARTIES:}

A) Decision-maker: British Museum Board of Trustees;

B) Third-parties: British \& Greek political parties/politicians; national constituencies; other national and international museums; archeological associations UNESCO/UN; EU/Council of Europe; media; individuals with powerful voice within the art world; internationally recognizable/respected individuals; private collectors.

\section{NO DEAL/ WORST CASE SCENARIO:}

Alienation between the two parties, lack of collaboration in international exchange of cultural artifacts, Parthenon Marbles remain at the British Museum

\section{PERCEPTIONS:}

A) Greeks: blame the British for past actions, feel that the British deprived them of their cultural property, see British as possibly desensitized and philistine, feel offended for the British not deeming them appropriate to carry their own cultural heritage,

B) British: mistrust that the Greeks will abide by a potential agreement, see Greeks as wanting to hoard art, see Greeks as being overly nationalistic in their claims, see Greeks as wanting a return of the Parthenon Marbles without further relationship.

\section{COMMUNICATION:}

Chopped communication, discussion has been focused on past blame rather than future cooperation, communication has been emotional, parties have approached the issue as requiring a one-shot solution, (e.g. the full mass return of the Parthenon Marbles).

\section{STANDRADS (British):}

Strong sense of committing to agreements, strong sense of fairness and equity, value trust and transparency, high value of the law, efficient agenda setting - start with easy payouts then move towards harder incrementally. 


\begin{tabular}{|c|c|}
\hline $\begin{array}{l}\text { 5. PREPARATION: } \\
\text { Enough time should be given to } \\
\text { the negotiation in order for the par- } \\
\text { ties to establish a working connec- } \\
\text { tion. However, the negotiation } \\
\text { should not drag too long in order } \\
\text { to avoid frustration and cynicism. } \\
\text { Both parties arguably have similar } \\
\text { information over the other. }\end{array}$ & $\begin{array}{l}\text { 10. RE-EXAMINE GOALS: } \\
\text { Still realistic }\end{array}$ \\
\hline $\begin{array}{l}\text { QUADRANT III - OPTIONS / } \\
\text { RISK REDUCTION }\end{array}$ & QUADRANT IV - ACTIONS \\
\hline $\begin{array}{l}\text { 11. BRAINSTORM: } \\
\text { Create loan agreements benefi- } \\
\text { cial for both parties, trade other an- } \\
\text { tiquities, replace the entire collec- } \\
\text { tion with other antiquities of } \\
\text { similar caliber that have never been } \\
\text { displayed before, create touring } \\
\text { collections, place the Parthenon } \\
\text { Marbles in a special exhibition } \\
\text { where the British Museum receives } \\
\text { (part of) the revenue, offer exclu- } \\
\text { sive deals for the British Archaeo- } \\
\text { logical Association in excavations } \\
\text { and use of objects found under its } \\
\text { excavations, joint trusteeship, frac- } \\
\text { tional ownership, establish co- } \\
\text { educational programs for museum } \\
\text { personnel, waive liability, recog- } \\
\text { nize the work and care the foreign } \\
\text { museum has given to the artifacts. }\end{array}$ & $\begin{array}{l}\text { 16. BEST } \\
\text { OPTIONS/PRIORITIES: } \\
\text { Start incrementally, gain the } \\
\text { simultaneous support of third par- } \\
\text { ties, and create a vision of a long- } \\
\text { term future cooperation. Begin by } \\
\text { discussing action that can be estab- } \\
\text { lished in the short term, even ex- } \\
\text { tend a loan first as a gesture of } \\
\text { goodwill. Then move into long- } \\
\text { term plans. Do not delve into legal } \\
\text { discussion and blame for past ac- } \\
\text { tion and/or inaction. }\end{array}$ \\
\hline $\begin{array}{l}\text { 12. INCREMENTAL: } \\
\text { Start with discussing museum } \\
\text { cooperation first, nurture a climate } \\
\text { of international cultural exchange, } \\
\text { agree on a short/long term loan of } \\
\text { one or few pieces at first to build } \\
\text { trust. }\end{array}$ & $\begin{array}{l}\text { 17. PRESENTATION: } \\
\text { Establish a face-to-face negotia- } \\
\text { tion with the British Museum Trus- } \\
\text { tees individually and collectively. }\end{array}$ \\
\hline
\end{tabular}




\section{THIRD PARTIES:}

A) Common Enemies: lack of cooperation, lack of cultural property exchange, disapproval of political constituencies, illicit market for cultural antiquities, precedent setting, litigation

B) Influencers: UN/UNESCO, EU/Council of Europe, third states, international museums, national constituencies, archaeological associations, media, international civil society.

\section{FRAMING:}

Vision of a truly international cultural exchange that matches the emotional interests of source counties to the educational interests of museums. Acknowledge shared interests between Greek and the British Museum in a potential exchange, talk of shared long term standing profit stemming out of a successful collaboration. "There is nothing to lose and everything to win out of a valued relationship."

\section{ALTERNATIVES:}

Start establishing similar collaborations/ agreements with other international museums holding Greek antiquities to nurture a sense of trust and commitment to the renewed policy as well as to start setting up an individualized managed market.

\section{PROCESS:}

Set an agenda starting with easier short term steps; get agreement, then move to harder topics. Separate short-term plans and longterm plans. Agree to take breaks when emotion takes over the negotiation instead of walking out of the negotiation table. Take as many breaks as necessary.
19.

COMMITMENTS/INCENTIVES:

Focus on how you can make the British Museum even richer and more international than it currently is. Establish an interest in longterm commitment and collaboration. Allow for discussion on exclusive agreements with the British Museum on given artifacts.
20. NEXT STEPS:

Create a step-by-step plan of getting tangible incremental results. Schedule regular follow-up meetings keeping track of the progress made. Establish open communication links. Implement plans and agreement. 
Though the Four Quadrant model delves into a lot of the practicalities of an actual negotiation, it elucidates the important aspects on which a negotiation for the Parthenon Marbles should focus. (1) Framing the right vision under a balanced cultural nationalism/internationalism appreciation; (2) incremental steps to establish results; (3) transparency in order to address faulty perceptions of the other party; (4) a strategic influence of third parties; and (5) an appreciation of unequally valued interests in order to establish an exchange environment, are critical to a successful Parthenon Marbles negotiation for both parties. Ideas such as loan agreements, trading and exchange of cultural artifacts, touring collections, exclusive excavation agreements, joint trusteeship, fractional ownership, personnel education, and liability waivers all provide excellent starting points to a discussion not on how Greece can get the Parthenon Marbles back, but on how to form a partnership between Greece and the British Museum. Such partnership will successfully promote collaboration, international exchange of cultural heritage, as well as public access, education, and appreciation of invaluable pieces of the cultural heritage the Greeks created; a cultural heritage so great that is now shared by the entire world.

\section{CONCLUSION}

To this day the Parthenon Marbles remain at the British Museum despite consecutive requests for return. The case of the Parthenon Marbles epitomizes the fact that despite the increase in legal awareness over issues of cultural property, they still remain a politically convoluted terrain. Unlike traditional forms of property, cultural property falls into a grey area in between ownership rights and group notions of value. 150 The concept of cultural property also contains strong nationalist overtones while simultaneously requiring an internationalist approach. Although cultural property is integral to the life and identity of a group, it equally forms part of a bigger identity that connects mankind and is fundamental to the generation of art, learning, and scholarship.

150 Patty Gerstenblith, Identity and Cultural Property: The Protection of Cultural Property in the United States, 75 B.U. L. REV. 559, 567 (1995) [https://perma.cc/FPT7RPM6]. 
This article has sought to identify a trajectory towards a more effective approach on cultural property that transcends the traditional ownership versus value debate. It is set to substantiate three primary claims using the example of the Parthenon Marbles as an archetypal inquiry. First, arguments on both sides regarding ownership of cultural property are murky and only blur the path the discussion should follow. Margaret Radin's property for personhood theory provides a compelling case for inalienability of the Parthenon Marbles detached from the factual circumstances that surrounded their original alienation. Second, this article deconstructs the traditional division between cultural nationalism and cultural internationalism suggesting that the two notions can successfully coexist and bolster one another. Finally, capitalizing on this mutually enriching coexistence, this article propels a new strategy for Greece on the Parthenon Marbles using the Four Quadrant Negotiation Model based on past successful negotiations. The status quo that favors the retention of the Parthenon Marbles in the British Museum has the advantage of inertia on its side. ${ }^{151}$ However, this article, if nothing else, has attempted to shift the context of the discussion from one of legal title and ownership to one of negotiation, cooperation, and advancement of both nationalist and internationalist ideals. After all, a continued disregard for the needs of national groups and humankind alike would threaten to strip both off their individual and collective identities. This bears the risk of a result against what they equally stand for: the continuation of the past, through the present, into the future.

151 See David J. Bederman, Christopher J. Borgen, \& David A. Martin, International Law: A Handbook for Judges, 35 STUD. TRANSNAT'L LEG. POL. 1, 32 (2003) [https://perma.cc/P9YA-EZTR] ("[I]n 1903, an international arbitral tribunal ruled that there was sufficient consensus to make [repose] a rule of international claims practice."). 